\title{
Does Environmental Decentralization Improve Regional Green Innovation? Evidence from China
}

\author{
Nana Yang ( $\nabla$ yang916@njupt.edu.cn ) \\ Nanjing University of Posts and Telecommunications \\ Qiming Liu \\ Nanjing University of Finance and Economics
}

\section{Research Article}

Keywords: Environmental decentralization, green innovation, environmental management, China

Posted Date: September 15th, 2021

DOl: https://doi.org/10.21203/rs.3.rs-776640/v1

License: (c) (i) This work is licensed under a Creative Commons Attribution 4.0 International License. Read Full License 


\section{Does environmental decentralization improve regional green}

\section{innovation? Evidence from China}

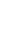

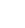

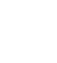

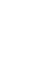

\section{Abstract}

8

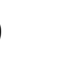
environmental management system plays an important role in improving environmental pollution and technology progress. Working from a heterogeneous perspective, this study investigates the effects of different types of environmental decentralization on regional green innovation using statistical data from 30 provinces in China over the period of 2000-2015. The results show that environmental decentralization (ED) promotes regional green innovation. Furthermore, according to different environmental management of levels and affairs, we divide environmental decentralization into provincial-level environmental decentralization (PED), municipal-level environmental decentralization (MED), and county-level environmental decentralization (CED); environmental administrative decentralization (EAD), environmental monitoring decentralization (EMD), and environmental supervision decentralization (ESD), respectively. There is also evidence suggesting that different types of environmental decentralization have varied effects on regional green innovation. These findings set out in this study are robust when different methods are employed. A further investigation indicates that the effects of different types of environmental decentralization on green innovation apparently differ across Chinese different regions. Some policy recommendations will help policymakers to determine more effective environmental decentralization.

\section{Keywords:}

28 Environmental decentralization; green innovation; environmental management; China

*Corresponding author. E-mail address: 9120201033@ nufe.edu.cn (Qiming Liu). 


\section{Introduction}

In recent decades, China achieves a miracle of rapid economic growth due to the adoption of reform and opening-up policies (Hao et al., 2020; Liu and Wang, 2017). After long-term economic growth, China, as the biggest developing country and the second-largest economy in the world, has faced several serious problems such as natural resource depletion and environmental pollution (Bian et al., 2019; Liu et al., 2017; Zhen et al., 2020). Thus, it is urgent to develop innovation capabilities within an environmental context, which can achieve the double-winning goal of environmental and economic benefits (Shen et al., 2020). It is noted that local governments play a vital role in stimulating the development of green innovation, because local governments can provide a better development environment and more effective financial and policy support.

In China, the decentralization reform is an important institutional factor affecting local government behavior (Zhou et al., 2020). For a long time, China was a centralized economy, emphasizing the role of the central government in public affairs. Now, China has become a highly decentralized economy by implementing its fiscal decentralization reforms and environmental decentralization system, therefore, local governments have more management rights in local fiscal and environmental governance (Batterbury and Fernando, 2006). Since 2008, China has been actively promoted environmental decentralization system, that is, the central government gives a lower level of government the corresponding autonomy and responsibilities in environmental management (Fredriksson and Wollscheid, 2014). Currently, local governments can exert their environmental governance rights and implement environmental protection policies in accordance with regional situations. Thus, can environmental decentralization affect green innovation? According to the proposal on the "13th FiveYear Plan", China has implemented the vertical environmental management system of environmental protection institutions. Therefore, China's environmental decentralization also have been further subdivided. According to different environmental management of affairs, Qi (2014) subdivided environmental 
decentralization into environmental administrative decentralization, environmental monitoring decentralization, environmental supervision decentralization. There is, however, little valid empirical evidence of the relationship between different types of environmental decentralization and green innovation.

This paper uses the panel data from 30 provinces in China from 2000-2015 to comprehensively estimate the relationship between environmental decentralization and green innovation. There are three main contributions of this study to the ongoing literature. First, we test for the effect of whether environment decentralization affects green innovation. It can enrich and improve the theoretical results of environment decentralization and has important practical significance for environmental governance and green innovation. Second, the effect mechanisms of different types of environmental decentralization are different. In addition to different environmental management of affairs, we divide environmental decentralization into provincial-level environmental decentralization (PED), municipal-level environmental decentralization (MED), and county-level environmental decentralization (CED) according to environmental management of levels. Moreover, this study has made an elaborate analysis of the effects of these different types of environmental decentralization on green innovation. It is favorable for assessing which kind of environmental decentralization can promote green innovation. Third, given the consideration of the imbalance of China's regional economic development, this study divides China into three regions: the eastern, central, and western regions and thereby compares the regional difference of the effect of environmental decentralization on green innovation. It is beneficial to precisely put forward the optimal combination of environmental decentralization targeting different regional green innovation.

The rest of the paper is organized as follows. Section 2 provides the literature review, which reviews the existing research on green innovation and environmental decentralization. Section 3 introduces the evolution and current situation of environmental decentralization in China. Section 4 explains data and estimation methods used in this study. Section 5 presents empirical results and analysis. Section 6 summarizes the conclusion and related policy implications. 


\section{Literature review}

In innovation research, green innovation is an important driving force for regional high-quality economic development by promoting technical progress and transforming regional environments. Green innovation is usually associated with the sustainable development of the ecological environment (Schiederig et al., 2012). Chen et al. (2006) described green innovation as "hardware or software innovation that is related to green products or processes, including the innovation in technologies that are involved in energy-saving, pollution-prevention, waste recycling, green product designs, or corporate environmental management". The most prominent terms used on similar topics to describe this innovation type are 'eco-innovation', 'environmental innovation', and 'sustainable innovation'. Fussler (1996) defined eco-innovations as 'new products and processes, which provide customer and business value but significantly decrease environmental impacts". Oltra and Jean (2009) defined environmental innovation as "innovations that consist of new or modified processes, practices, systems, and products which benefit the environment and so contribute to environmental sustainability". Sustainable innovation is defined as innovation that improves sustainability performance, where such performance includes ecological, economic, and social criteria" (Boons et al., 2013). In this paper, we draw on the work of Kunapatarawong and Martinez-Ros (2016), define green innovation as new processes, techniques and products to avoid or decrease environmental impacts.

Prior research has uncovered various determinants of green innovation from the firm level and region level. At the firm level, green innovation can be driven by both internal and external determinants. While the internal determinants include corporate governance (Amore and Bennedsen, 2016), corporate capabilities (Albort-Morant et al., 2016; Cuerva et al., 2014; Li et al., 2017), executive characteristics (Hao et al., 2019; Ren et al., 2021), literature on green innovation emphasized external determinants such as political capital (Lin et al., 2014), institutional pressure (Chen et al., 2018; Leenders and Chandra, 2013), outward foreign direct investment (Yang, Z. et al., 2020). At the region level, the role of environmental policy tools on green innovation has been 
explored (Shen et al., 2020), especially environmental regulation (Cai et al., 2020; Dong et al., 2020; Hu and Liu, 2019; Pan, X. et al., 2020; Song et al., 2020). Besides, there is evidence that fiscal decentralization has an effect on green innovation (Zhou et al., 2020).

More recently, environmental decentralization has been a major focus of scholars, the relationship between environmental decentralization and green innovation has also been explored. For example, Feng et al. (2020) examine the relationship between environmental decentralization on green innovation in China for the period of 20062015 by the spatial Durbin model. They demonstrate that there exists the local effect and spatial effect of environmental decentralization on green innovation. The findings of the study also indicate that different types of environmental decentralization (environment decentralization of finance and environmental decentralization of government reform) have different effects on green innovation. Based on panel data of 30 Chinese provinces, Zhang and $\mathrm{Li}$ (2020) study the relationship between environmental decentralization, environmental protection investment, and green technology innovation and find that environmental decentralization inhibits green technology innovation in the short term, while promotes green technology innovation in the long run.

\section{Environmental decentralization in China}

Originated from the decentralization system and environmental federalism, environmental decentralization is an environmental management system. In China, environmental management system reform has approximately evolved through three stages (Qi, 2014). The first stage, from 1973 to 1993, established a system of decentralized environmental management and division of administrative power. The second stage run from 1994 through 2007 initially, when environmental management presents centralization characteristics under the decentralized system. The third stage is from 2008 onwards, when the control intensity of central government and environmental governance incentives of local governments have been strengthened under the decentralized system. Thus, in this paper, we describe environmental 
decentralization as the division of environmental management powers and responsibilities between central and local governments (Wu et al., 2020).

Since 2008, the central government gives local governments more environmental management rights in China. Nowadays, China has established the vertical environmental management system, which combines the central and local governments at different levels of management (Liu et al., 2012). Specially, The Ministry of Environmental Protection (MEP) of the central government is mainly responsible for enacting environmental laws, while local Environmental Protection Bureau (EPB) is responsible for implementing these laws and formulating local environmental regulations that are more suitable for the region. Thus, for local EPBs, they are mainly influenced by local governments rather than the MEP at the central level. Moreover, China's multi-level environmental management system mainly includes four levels: central, provincial, municipal, and county levels. The four-level environmental management agencies belong to the government of the corresponding level (see Figure 1). Figure 2 plots the proportion of staff in environmental management agencies at different levels in China from 2000 to 2015. It can be seen that during 2000-2015, the distribution of staff in environmental management agencies at all levels is basically stable. By computing the 2000-2015 average, we can find that $67.2 \%$ of China's environmental management agencies were distributed at the county-level; $24.7 \%$ were distributed at the municipal-level; $6.8 \%$ were distributed at the provincial-level, and only $1.3 \%$ was distributed at the central-level.

In addition to environmental management of levels, environmental management of affairs mainly includes environmental administrative, environmental monitoring and environmental supervision (Qi, 2014). As Zou et al. (2019) have been mentioned, environmental administrative is primarily responsible for formulating local environmental protection policies. These policies are required in accordance with local economic development and the targets of the central government. Environmental monitoring mainly involves monitoring and assessing local environmental quality, while environmental supervision is mainly responsible for environmental law enforcement and supervision. As shown in Figure 3, during the period 2000-2015, 25.45\% 
177 of environmental management personnel are engaged in environmental administrative

178 affairs, $28.47 \%$ of environmental management personnel are engaged in environmental

179 monitoring affairs, and $29.63 \%$ of environmental management personnel are engaged

180 in environmental supervision affairs.

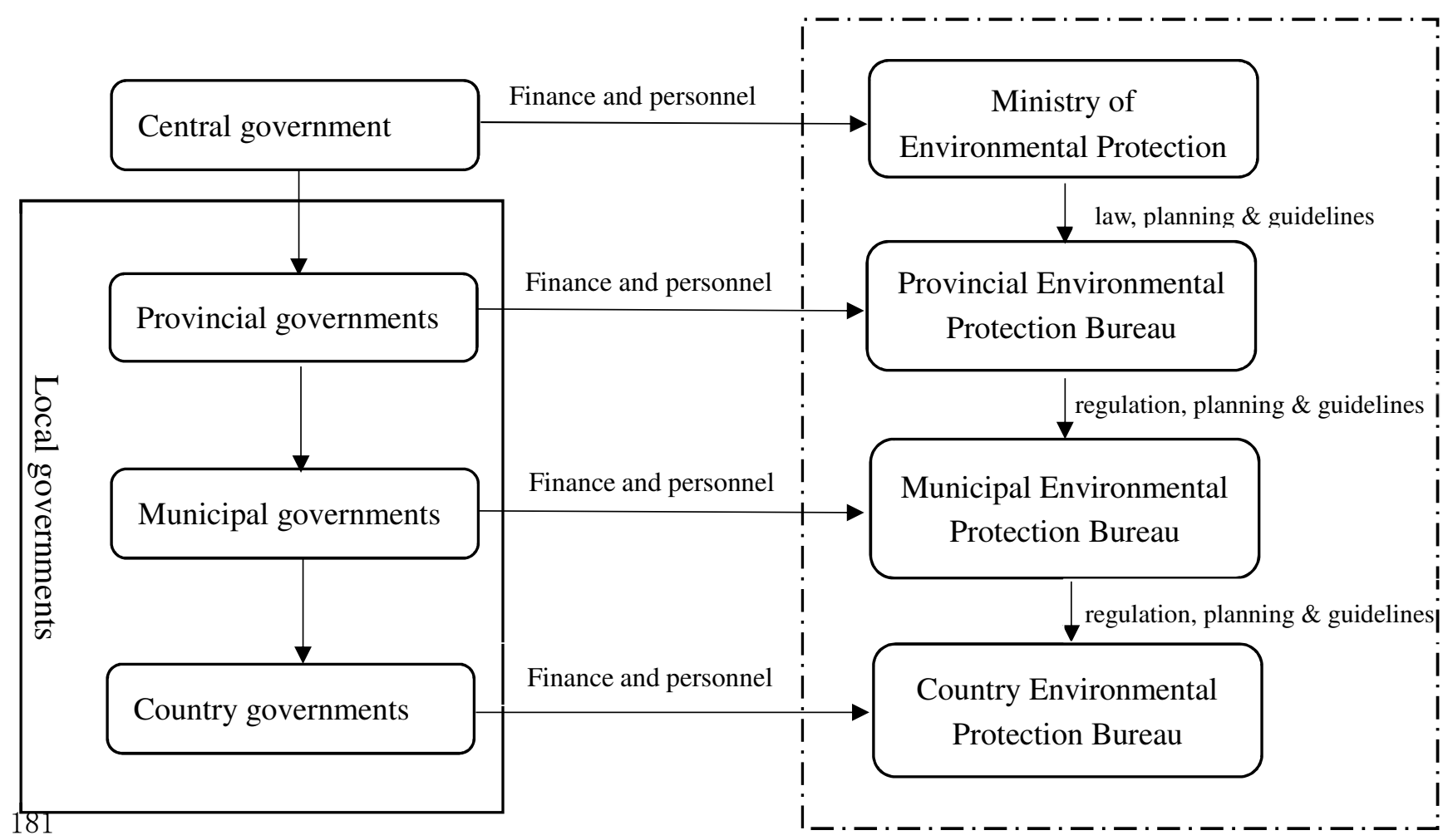

Figure 1 Multi-level environmental management system in China

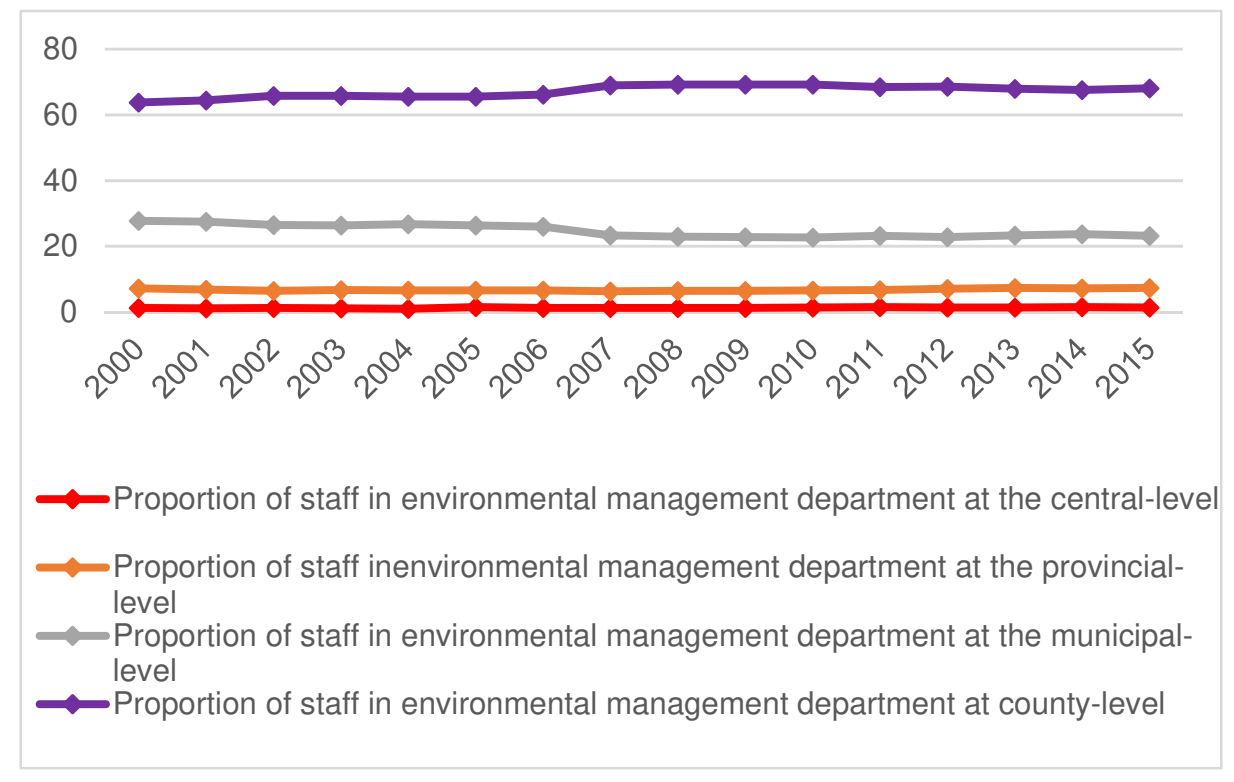

184 Figure 2 The proportion of staff in environmental management department at different levels 


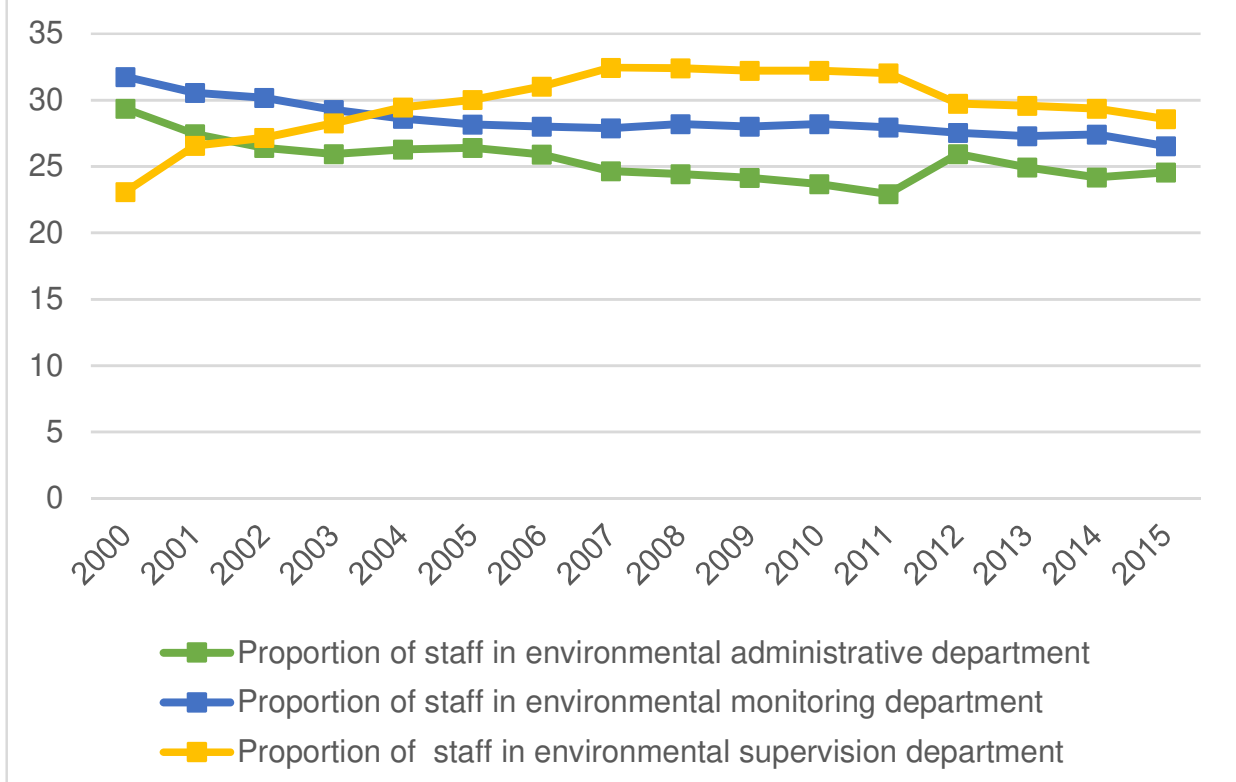

Figure 3 The proportion of staff in different environmental management of affairs

\section{Data and empirical methodology}

\subsection{Data and variables}

This study used a panel dataset of 30 provinces from 2000 to 2015 . All of the data used come from National Intellectual Property, the China Environment Yearbook, the China Statistical Yearbook on Science and Technology, and the China Statistical Yearbook.

\subsubsection{Dependent variable}

Green innovation $(G I)$. Previous studies have indicated that the number of green patents is an important measure of China's green innovation (Feng et al., 2020; Pan, X. et al., 2020; Wang et al., 2019; Zhang and Li, 2020). Following Pan, X. et al. (2020) and Zhang and Li (2020), the proxy indicator of GI in this paper is the number of green invention and utility model patent applications, which is determined from environmental technology classified by the World Intellectual Property Organization (WIPO).

\subsubsection{Core variables}

Environmental decentralization (ED). In line with the current studies, we use the 
number of central and local personnel within the environmental protection system to measure the degree of environmental decentralization. In addition, according to different environmental management of levels, environmental decentralization includes provincial-level environmental decentralization (PED), municipal-level environmental decentralization (MED), and county-level environmental decentralization (CED). According to different environmental management of affairs, environmental decentralization includes environmental administrative decentralization (EAD), environmental monitoring decentralization (EMD), and environmental supervision decentralization (ESD). The calculation formulae of various types of environmental decentralization are as follows:

$E D_{i t}=\frac{E S P_{i t} / P O P_{i t}}{H S P_{t} / P O P_{t}} *\left(1-G D P_{i t} / G D P_{t}\right)$

$$
\text { PESP }
$$

$P E D_{i t}=\frac{P E S P_{i t} / P O P_{i t}}{H S P_{t} / P O P_{t}} *\left(1-G D P_{i t} / G D P_{t}\right)$

$$
M E S P_{i t}
$$

$M E D_{i t}=\frac{M E S P_{i t} / P O P_{i t}}{H S P_{t} / P O P_{t}} *\left(1-G D P_{i t} / G D P_{t}\right)$

$$
\text { CESP }
$$

$C E D_{i t}=\frac{C E S P_{i t} / P O P_{i t}}{H S P_{t} / P O P_{t}} *\left(1-G D P_{i t} / G D P_{t}\right)$

$$
E A D_{i t}=\frac{E S A_{i t} / P O P_{i t}}{H S A_{t} / \operatorname{POP}_{t}} *\left(1-G D P_{i t} / G D P_{t}\right)
$$

$219 \quad E S D_{i t}=\frac{1 P O P_{i t}}{H S S_{t} / P_{P O P}} *\left(1-G D P_{i t} / G D P_{t}\right)$

where $H S P_{t}, H S A_{t}, H S M_{t}$ and $H S S_{t}$ indicate the national total number of personnel 
in the environmental protection system, environmental administrative, environmental monitoring, and environmental supervision in year $t$, respectively. $E S P_{i t}, P E S P_{i t}$, $M E S P_{i t}$ and $C E S P_{i t}$ represent the total number of personnel in the environmental protection system, provincial-level environmental protection system, municipal-level environmental protection system, and county-level environmental protection system in year $t$ of region $i$, respectively. $E S A_{i t}, E S M_{i t}$ and $E S S_{i t}$ represent the total number of personnel in environmental protection administrative, environmental monitoring, and environmental supervision in year $t$ of region $i$, respectively. $P O P_{t}$ and $G D P_{t}$ represent the total population and GDP of the country in year $t . P O P_{i t}$ and $G D P_{i t}$ represent the total population and GDP in year $t$ of region $i .1-G D P_{i t} / G D P_{t}$ is the economic deflator factor to lower the impact of heterogeneity of regional economies of scale.

\subsubsection{Control variables}

In addition to the main variables, the following variables are selected as the control variables that have a considerable impact on regional green innovation. (1) $R \& D$ input $(R \& D)$. The green innovation of each region is positively related to $\mathrm{R} \& \mathrm{D}$ input, such as R \& D expenditures (Luo et al., 2021). The bigger the intensity of R\&D input, the stronger the capacity for green technology innovation. This paper uses the proportion of R \& D expenditures of a region to GDP as a proxy for the intensity of R\&D input. (2) Financial development (FD). Financial support is an important source of capital for green innovation, which has significant positive effects in promoting green innovation. Following the previous studies (Zhao et al., 2021; Zhou et al., 2019), the ratio of bank and financial institution loan balance to GDP is used to measure the level of financial development. (3) Human capital (HC). The improvement in human capital is conducive to increasing the quality of the workforce in the region, thus improving green innovation. Human capital is determined by the proportion of the population of undergraduate level or above education (Ning et al., 2016). (4) Marketization level (ML). According to the work of Zeng et al. (2021) and Zheng (2021), we select the "China marketization index" 
249 to evaluate China's marketization level, which is measured in five fields using Principal

250 Component Analysis developed by the National Economic Research Institute (NERI)

251 Reform Foundation.

252 Table 1 provides the measurements of all variables. Descriptive statistics for 253 variables are reported in Table 2.

Table 1 The measurements of all variables

\begin{tabular}{ccc}
\hline Variables & Measurement & Data source \\
\hline $\begin{array}{c}\text { Regional green innovation } \\
\text { (RGI) }\end{array}$ & $\begin{array}{c}\text { Green invention and utility model } \\
\text { patent applications } \\
\text { Environmental decentralization } \\
\text { (ED) } \\
\text { R\&D input } \\
\text { (R\&D) }\end{array}$ & Intellectual Property Office \\
Sinancial development & The ratio of R\&D expenditures over & CCSY (2000-2015) \\
(FD) & The regional GDP & CESY (2000-2015) \\
Human capital (HC) & institution loan balance to GDP & CCSY (2000-2015) \\
The proportion of the population of & CCSY (2000-2015) \\
Marketization level & undergraduate level or above education & \\
(ML) & China marketization index & The report of China's \\
& & Provincial Market Index \\
\hline
\end{tabular}

255 Note: CCSY: China City Statistical Yearbook; CESY:China Environmental Statistics Yearbook

Table 2 Descriptive statistics of variables

\begin{tabular}{cccccc}
\hline & Observations & Mean & SD & Min & Max \\
\hline GI & 480 & 6.037 & 1.667 & 0.693 & 10.01 \\
ED & 480 & 0.975 & 0.357 & 0.414 & 2.29 \\
PED & 480 & 0.027 & 0.010 & 0.009 & 0.059 \\
MED & 480 & 0.032 & 0.021 & 0 & 0.088 \\
CED & 480 & 0.032 & 0.027 & 0 & 0.139 \\
EAD & 480 & 1 & 0.378 & 0.378 & 2.419 \\
EMD & 480 & 1.004 & 0.369 & 0.389 & 2.558 \\
ESD & 480 & 0.945 & 0.52 & 0.127 & 2.53 \\
R\&D & 480 & 1.238 & 1.021 & 0.146 & 6.014 \\
FD & 480 & 1.114 & 0.366 & 0.537 & 2.585 \\
HC & 480 & 1.416 & 0.721 & 0.213 & 3.565 \\
ML & 480 & 5.951 & 1.807 & 2.37 & 10.92 \\
\hline
\end{tabular}




\subsection{Model specification}

In order to explore the effect of environmental decentralization on green innovation, we establish the fixed effects model:

$$
\operatorname{LnGI}_{i, t}=a_{0}+a_{1} E D_{i, t}+a_{2} X_{i, t}+u_{i}+\lambda_{t}+\varepsilon_{i, t}
$$

where $i, t$ present the province and year respectively. As the dependent variable, $L n G I_{i, t}$ stands for green innovation. The key explanatory variable $E D$ refers to environmental decentralization. $X_{i, t}$ is a set of control variables that may affect green innovation, including R \& D input (R\&D), financial development (FD), human capital (HC), and marketization level (ML). In addition, $u_{i}$ denotes the regional fixed effect, $\lambda_{t}$ represents the time fixed effect; $\varepsilon_{i t}$ signifies the unobserved error term.

\section{Empirical analysis results}

\subsection{Results of national region}

Table 3 reports the regression results of the national region. In Table 3, the regression coefficient of environmental decentralization is 0.206 , which is significant at $10 \%$, indicating that environmental decentralization has a positive significant impact on regional green innovation. In addition, the regression coefficients of provincial-level environmental decentralization and municipal-level environmental decentralization are 7.033 and 3.807, which are significant at $1 \%$ and $10 \%$ levels, respectively, while the regression coefficients of county-level environmental decentralization is 3.342 but does not have statistical significance. The results indicate that regions characterized by provincial-level environmental decentralization and municipal-level environmental decentralization have positive impacts on local green innovation. Meanwhile, the regression coefficients of environmental administrative decentralization and environmental monitoring decentralization are significantly positive, whereas the regression coefficient of environmental supervision decentralization is positive but not significant. The results imply that supporting policies involving ongoing supervision 
283 that may not have a positive impact on green innovation (Ran et al., 2020).

Table 3 The regression results of national region

\begin{tabular}{|c|c|c|c|c|c|c|c|}
\hline VARIABLES & Model 1 & Model 2 & Model 3 & Model 4 & Model 5 & Model 6 & Model 7 \\
\hline \multirow[t]{2}{*}{$\mathrm{ED}$} & $0.206^{*}$ & & & & & & \\
\hline & (1.92) & & & & & & \\
\hline \multirow[t]{2}{*}{ PED } & & $7.033 * * *$ & & & & & \\
\hline & & $(2.64)$ & & & & & \\
\hline \multirow[t]{2}{*}{ MED } & & & $3.807 *$ & & & & \\
\hline & & & (1.70) & & & & \\
\hline \multirow[t]{2}{*}{ CED } & & & & 3.342 & & & \\
\hline & & & & (1.16) & & & \\
\hline \multirow[t]{2}{*}{ EAD } & & & & & $0.137 * *$ & & \\
\hline & & & & & $(2.01)$ & & \\
\hline \multirow[t]{2}{*}{ EMD } & & & & & & $0.134 *$ & \\
\hline & & & & & & (1.66) & \\
\hline \multirow[t]{2}{*}{ ESD } & & & & & & & 0.086 \\
\hline & & & & & & & $(1.25)$ \\
\hline \multirow[t]{2}{*}{$\mathrm{R} \& \mathrm{D}$} & $0.198 * * *$ & $0.188 * * *$ & $0.185 * * *$ & $0.175 * * *$ & $0.183 * * *$ & $0.184 * * *$ & $0.185 * * *$ \\
\hline & $(3.55)$ & $(3.50)$ & $(3.40)$ & (3.24) & $(3.38)$ & $(3.38)$ & (3.34) \\
\hline \multirow[t]{2}{*}{ FD } & $0.574 * * *$ & $0.616 * * *$ & $0.602 * * *$ & $0.577 * * *$ & $0.576 * * *$ & $0.586 * * *$ & $0.602 * * *$ \\
\hline & $(5.95)$ & (6.50) & (6.33) & $(5.86)$ & $(5.99)$ & $(6.12)$ & $(6.31)$ \\
\hline \multirow[t]{2}{*}{$\mathrm{HC}$} & $0.401 * * *$ & $0.398 * * *$ & $0.373 * * *$ & $0.436 * * *$ & $0.405 * * *$ & $0.395 * * *$ & $0.424 * * *$ \\
\hline & $(6.42)$ & $(6.38)$ & $(5.66)$ & $(6.50)$ & $(6.48)$ & $(6.28)$ & $(6.63)$ \\
\hline \multirow[t]{2}{*}{ ML } & $0.073 * * *$ & $0.072 * * *$ & $0.075 * * *$ & $0.071 * * *$ & $0.071 * * *$ & $0.075 * * *$ & $0.071 * * *$ \\
\hline & $(2.80)$ & $(2.76)$ & (2.84) & $(2.69)$ & $(2.71)$ & $(2.84)$ & $(2.70)$ \\
\hline \multirow[t]{2}{*}{ Constant } & $3.040 * * *$ & $3.030 * * *$ & $3.115 * * *$ & $3.153 * * *$ & $3.125 * * *$ & $3.105 * * *$ & $3.146 * * *$ \\
\hline & $(15.48)$ & $(16.70)$ & $(17.20)$ & $(17.08)$ & $(18.05)$ & $(16.79)$ & $(17.08)$ \\
\hline Year dummies & YES & YES & YES & YES & YES & YES & YES \\
\hline $\mathrm{N}$ & 480 & 480 & 480 & 480 & 480 & 480 & 480 \\
\hline R-squared & 0.961 & 0.961 & 0.961 & 0.961 & 0.961 & 0.961 & 0.961 \\
\hline
\end{tabular}

285 Notes: $\mathrm{t}$ statistics in parentheses. $* * *, * * *$ indicates significant at the level of $1 \%, 5 \%$, and $10 \%$.

\subsection{Results of subsample}

287 The development level of Chinese economy is unequal in different regions (Pan, X.F.

288 et al., 2020; Yang, N.N. et al., 2020). To identify the impact of environmental

289 decentralization on green innovation across regions, we classify the total samples into 
290 three regions based on their geographical location: eastern region, central region and

291 western region. The eastern region covers 11 provinces and municipalities, referring to

292 Beijing, Tianjin, Hebei, Liaoning, Shanghai, Jiangsu, Zhejiang, Fujian, Shandong,

293 Guangdong, and Hainan provinces. The central region includes 8 provinces, Shangxi,

294 Heilongjiang, Jilin, Anhui, Jiangxi, Henan, Hubei, and Hunan. The western region

295 comprises 11 provinces, municipalities, and autonomous regions, Inner Mongolia,

296 Guangxi, Chongqing, Sichuan, Guizhou, Yunnan, Shanxi, Gansu, Qinghai, Ningxia and

297 Xinjiang. The estimation results of the three regions are presented in Tables 4-6.

$298 \quad$ Table 4 The regression results of eastern region

\begin{tabular}{|c|c|c|c|c|c|c|c|}
\hline VARIABLES & Model 1 & Model 2 & Model 3 & Model 4 & Model 5 & Model 6 & Model 7 \\
\hline ED & $\begin{array}{c}0.342 * * \\
(1.99)\end{array}$ & & & & & & \\
\hline PED & & $\begin{array}{c}10.464 * * * \\
(2.92)\end{array}$ & & & & & \\
\hline MED & & & $\begin{array}{c}7.145^{* * *} \\
(2.88)\end{array}$ & & & & \\
\hline CED & & & & $\begin{array}{l}-3.380 \\
(-0.83)\end{array}$ & & & \\
\hline EAD & & & & & $\begin{array}{c}0.340 * * \\
(2.60)\end{array}$ & & \\
\hline EMD & & & & & & $\begin{array}{l}0.061 \\
(0.57)\end{array}$ & \\
\hline ESD & & & & & & & $\begin{array}{l}0.123 \\
(1.28)\end{array}$ \\
\hline Control variable & YES & YES & YES & YES & YES & YES & YES \\
\hline Constant & $\begin{array}{c}3.478 * * * \\
(10.51)\end{array}$ & $\begin{array}{c}3.508 * * * \\
(12.66)\end{array}$ & $\begin{array}{c}3.619 * * * \\
(13.92)\end{array}$ & $\begin{array}{c}4.067 * * * \\
(13.96)\end{array}$ & $\begin{array}{c}3.513 * * * \\
(12.25)\end{array}$ & $\begin{array}{c}3.840 * * * \\
(13.11)\end{array}$ & $\begin{array}{c}3.763 * * * \\
(13.65)\end{array}$ \\
\hline Year dummies & YES & YES & YES & YES & YES & YES & YES \\
\hline $\mathrm{N}$ & 176 & 176 & 176 & 176 & 176 & 176 & 176 \\
\hline R-squared & 0.974 & 0.975 & 0.975 & 0.973 & 0.974 & 0.973 & 0.974 \\
\hline
\end{tabular}

299 Notes: $t$ statistics in parentheses. $* * *, * *, *$ indicates significant at the level of $1 \%, 5 \%$, and $10 \%$.

301 As seen in Tables 4-6, the regression coefficients of environmental decentralization,

302 provincial-level environmental decentralization, municipal-level environmental

303 decentralization, environmental administrative decentralization and environmental 
monitoring decentralization in the eastern region are significantly positive, which is consistent with the national region. Furthermore, the regression coefficients of environmental decentralization, county-level environmental decentralization, environmental monitoring decentralization, and environmental supervision decentralization in the central region are positive and pass the significance test. Finally, the regression coefficient of environmental administrative decentralization is significantly positive in the western region. Note that the regression coefficient of environmental supervision decentralization is negative and passes the significant test at $5 \%$ level, indicating that environmental supervision decentralization in the western region has a significant negative effect on green innovation.

\begin{tabular}{lccc}
\hline VARIABLES & Model 1 & Model 2 & Model 3 \\
\hline ED & $0.769 * * *$ & & \\
& $(3.47)$ & & \\
PED & & 2.726 & \\
& & $(0.68)$ & \\
MED & & & 4.156 \\
& & & $(0.85)$
\end{tabular}

CED $16.176^{* * * *}$

EAD 0.057

EMD $0.342 *$

ESD

$0.342 * * *$

\begin{tabular}{lccccccc} 
Control variable & YES & YES & YES & YES & YES & YES & YES \\
Constant & $1.798^{* * *}$ & $2.336 * * *$ & $2.236^{* * *}$ & $1.849 * * *$ & $2.443 * * *$ & $2.049 * * *$ & $2.232 * * *$ \\
& $(4.49)$ & $(5.76)$ & $(5.05)$ & $(4.83)$ & $(6.52)$ & $(4.83)$ & $(6.01)$ \\
Year dummies & YES & YES & YES & YES & YES & YES & YES \\
N & 128 & 128 & 128 & 128 & 128 & 128 & 128 \\
R-squared & 0.979 & 0.977 & 0.977 & 0.980 & 0.977 & 0.978 & 0.978 \\
\hline
\end{tabular}

315 Notes: $t$ statistics in parentheses. $* * *, * *, *$ indicates significant at the level of $1 \%, 5 \%$, and $10 \%$. 


\begin{tabular}{|c|c|c|c|c|c|c|c|}
\hline VARIABLES & Model 1 & Model 2 & Model 3 & Model 4 & Model 5 & Model 6 & Model 7 \\
\hline \multirow[t]{2}{*}{ ED } & 0.075 & & & & & & \\
\hline & $(0.33)$ & & & & & & \\
\hline \multirow[t]{2}{*}{ PED } & & -3.347 & & & & & \\
\hline & & $(-0.50)$ & & & & & \\
\hline \multirow[t]{2}{*}{ MED } & & & 4.954 & & & & \\
\hline & & & $(0.52)$ & & & & \\
\hline \multirow[t]{2}{*}{ CED } & & & & -0.360 & & & \\
\hline & & & & $(-0.05)$ & & & \\
\hline \multirow[t]{2}{*}{ EAD } & & & & & $0.246 * *$ & & \\
\hline & & & & & $(2.35)$ & & \\
\hline \multirow[t]{2}{*}{ EMD } & & & & & & -0.199 & \\
\hline & & & & & & $(-1.03)$ & \\
\hline \multirow[t]{2}{*}{ ESD } & & & & & & & $-0.367 * *$ \\
\hline & & & & & & & $(-2.28)$ \\
\hline Control variable & YES & YES & YES & YES & YES & YES & YES \\
\hline \multirow[t]{2}{*}{ Constant } & $3.021 * * *$ & $3.162 * * *$ & $2.975 * * *$ & $3.080 * * *$ & $2.948 * * *$ & $3.228 * * *$ & $3.522 * * *$ \\
\hline & $(9.20)$ & $(9.31)$ & $(8.62)$ & $(9.29)$ & (10.19) & $(9.91)$ & (10.17) \\
\hline Year dummies & YES & YES & YES & YES & YES & YES & YES \\
\hline $\mathrm{N}$ & 176 & 176 & 176 & 176 & 176 & 176 & 176 \\
\hline R-squared & 0.960 & 0.960 & 0.960 & 0.960 & 0.961 & 0.960 & 0.961 \\
\hline
\end{tabular}

318 Notes: $\mathrm{t}$ statistics in parentheses. $* * *, * * *$ indicates significant at the level of $1 \%, 5 \%$, and $10 \%$.

\section{$319 \quad 5.3$ Robustness tests}

320 To verify the robustness of previous analysis results, we also perform some additional

321 robustness tests. First, we employ an alternative measurement of regional green

322 innovation. Following Yang, N. et al. (2020) in using invention patent applications to

323 measure innovation, we employ the number of green invention patent applications as a

324 different proxy for green innovation. The results reported in Table 7 remain largely the 325 same.

326 Then, we remove the economic deflator factor to measure environmental 327 decentralization. The results are reported in Table 8 and demonstrate that the 328 significance and signs of the coefficients for the main variables remain consistent with 
the above findings.

330 Finally, we drew on the work of Yu et al. (2021), use spatial panel models to explore

331 the impact of environmental decentralization on regional green innovation. We first 332 conduct the Moran's I test for spatial correlation of regional green innovation and 333 environmental decentralization. Table 9 demonstrates the Moran's I test results, which 334 indicates that regional green innovation and environmental decentralization show a 335 strong positive spatial correlation. Then, following the work of Zang and Liu (2020), 336 we use standardized spatial inverse-distance weight matrix (W) and spatial Durbin 337 model (SDM) to estimate the regression effects, because SDM assumes that both the 338 dependent and the explanatory variables are spatially correlated, which is consistent 339 with the Moran's I test. Table 10 exhibits the estimated results of SDM. The spatial 340 autoregressive coefficient $\rho$ is significantly positive and shows that green innovation

341 from the surrounding provinces affect local green innovation. Although a different 342 estimation method, that is SDM, is employed, we find that the results remain are 343 basically in line with those we obtain from non-spatial settings.

344 Table 7 Robustness check: alternative measurement of regional green innovation

\begin{tabular}{|c|c|c|c|c|c|c|c|}
\hline VARIABLES & Model 1 & Model 2 & Model 3 & Model 4 & Model 5 & Model 6 & Model 7 \\
\hline ED & $\begin{array}{c}0.334 * * \\
(2.52)\end{array}$ & & & & & & \\
\hline PED & & $\begin{array}{c}9.662 * * * \\
(2.92)\end{array}$ & & & & & \\
\hline MED & & & $\begin{array}{l}4.684 * \\
(1.69)\end{array}$ & & & & \\
\hline CED & & & & $\begin{array}{l}0.692 \\
(0.19)\end{array}$ & & & \\
\hline EAD & & & & & $\begin{array}{c}0.244 * * * \\
(2.90)\end{array}$ & & \\
\hline EMD & & & & & & $\begin{array}{c}0.211 * * \\
(2.10)\end{array}$ & \\
\hline ESD & & & & & & & $\begin{array}{l}0.040 \\
(0.47)\end{array}$ \\
\hline Control variable & YES & YES & YES & YES & YES & YES & YES \\
\hline
\end{tabular}




\begin{tabular}{lccccccc} 
Constant & $1.758 * * *$ & $1.799 * * *$ & $1.936 * * *$ & $2.092 * * *$ & $1.875 * * *$ & $1.872 * * *$ & $2.060 * * *$ \\
& $(7.22)$ & $(7.99)$ & $(8.60)$ & $(9.10)$ & $(8.75)$ & $(8.16)$ & $(8.98)$ \\
Year dummies & YES & YES & YES & YES & YES & YES & YES \\
$\mathrm{N}$ & 480 & 480 & 480 & 480 & 480 & 480 & 480 \\
R-squared & 0.949 & 0.949 & 0.948 & 0.948 & 0.949 & 0.948 & 0.948 \\
\hline
\end{tabular}

345 Notes: $t$ statistics in parentheses. $* * *, * *, *$ indicates significant at the level of $1 \%, 5 \%$, and $10 \%$.

346

347 Table 8 Robustness check: alternative measurement of environmental decentralization

\begin{tabular}{|c|c|c|c|c|c|c|c|}
\hline VARIABLES & Model 1 & Model 2 & Model 3 & Model 4 & Model 5 & Model 6 & Model 7 \\
\hline ED & $\begin{array}{l}0.205^{* *} \\
(1.97)\end{array}$ & & & & & & \\
\hline PED & & $\begin{array}{l}6.937 * * * \\
(2.72)\end{array}$ & & & & & \\
\hline MED & & & $\begin{array}{l}3.892 * \\
(1.83)\end{array}$ & & & & \\
\hline CED & & & & $\begin{array}{l}3.531 \\
(1.28)\end{array}$ & & & \\
\hline EAD & & & & & $\begin{array}{l}0.137 * * \\
(2.06)\end{array}$ & & \\
\hline EMD & & & & & & $\begin{array}{l}0.136^{*} \\
(1.73)\end{array}$ & \\
\hline ESD & & & & & & & $\begin{array}{l}0.085 \\
(1.29)\end{array}$ \\
\hline Control variable & YES & YES & YES & YES & YES & YES & YES \\
\hline Constant & $\begin{array}{l}3.035 * * * \\
(15.48)\end{array}$ & $\begin{array}{l}3.027 * * * \\
(16.76)\end{array}$ & $\begin{array}{l}3.106 * * * \\
(17.20)\end{array}$ & $\begin{array}{l}3.143 * * * \\
(17.06)\end{array}$ & $\begin{array}{l}3.122 * * * \\
(18.02)\end{array}$ & $\begin{array}{l}3.100 * * * \\
(16.77)\end{array}$ & $\begin{array}{l}3.143^{* * *} \\
(17.11)\end{array}$ \\
\hline Year dummies & YES & YES & YES & YES & YES & YES & YES \\
\hline $\mathrm{N}$ & 480 & 480 & 480 & 480 & 480 & 480 & 480 \\
\hline R-squared & 0.961 & 0.961 & 0.961 & 0.961 & 0.961 & 0.961 & 0.961 \\
\hline
\end{tabular}

348 Notes: t statistics in parentheses. $* * *, * *, *$ indicates significant at the level of $1 \%, 5 \%$, and $10 \%$.

349

350

Table 9 The Moran's I test results

\begin{tabular}{ccccccccc}
\hline Year & $\begin{array}{c}\text { GI } \\
\text { Moran's I }\end{array}$ & $\begin{array}{c}\text { ED } \\
\text { Moran's I }\end{array}$ & $\begin{array}{c}\text { PED } \\
\text { Moran's I }\end{array}$ & $\begin{array}{c}\text { MED } \\
\text { Moran's I }\end{array}$ & $\begin{array}{c}\text { CED } \\
\text { Moran's I }\end{array}$ & $\begin{array}{c}\text { EAD } \\
\text { Moran's I }\end{array}$ & $\begin{array}{c}\text { EMD } \\
\text { Moran's I }\end{array}$ & $\begin{array}{c}\text { ESD } \\
\text { Moran's I }\end{array}$ \\
\hline 2000 & $0.161 * *$ & $0.284 * * *$ & $0.297 * * *$ & $0.198 * * *$ & $0.195 * * *$ & $0.379 * * *$ & $0.2 * * *$ & $0.165 * *$ \\
2001 & $0.199 * * *$ & $0.29 * * *$ & $0.259 * * *$ & $0.113 * * *$ & $0.183 * * *$ & $0.381 * * *$ & $0.214 * * *$ & $0.13 * *$ \\
2002 & $0.188 * * *$ & $0.317 * * *$ & $0.216 * * *$ & $0.163 * * *$ & $0.177 * *$ & $0.387 * * *$ & $0.22 * * *$ & $0.216 * * *$
\end{tabular}




\begin{tabular}{|c|c|c|c|c|c|c|c|c|}
\hline 2003 & $0.229 * * *$ & $0.29 * * *$ & $0.221 * * *$ & $0.123 * * *$ & $0.162 * *$ & $0.342 * * *$ & $0.219 * * *$ & $0.16 * *$ \\
\hline 2004 & $0.212 * * *$ & $0.31 * * *$ & $0.26^{* * *}$ & $0.121 * * *$ & $0.178 * * *$ & $0.402 * * *$ & $0.191 * * *$ & $0.127 * *$ \\
\hline 2005 & $0.24 * * *$ & $0.288 * * *$ & $0.27 * * *$ & $0.14 * * *$ & $0.155^{* *}$ & $0.311 * * *$ & $0.203 * * *$ & $0.122 * *$ \\
\hline 2006 & $0.229 * * *$ & $0.301 * * *$ & $0.273 * * *$ & $0.17 * * *$ & $0.167 * *$ & $0.32 * * *$ & $0.231 * * *$ & $0.152 * *$ \\
\hline 2007 & $0.271 * * *$ & $0.314 * * *$ & $0.367 * * *$ & $0.151 * * *$ & $0.18 * * *$ & $0.306 * * *$ & $0.229 * * *$ & $0.152 * *$ \\
\hline 2008 & $0.243 * * *$ & $0.335 * * *$ & $0.368 * * *$ & $0.168 * *$ & $0.174 * * *$ & $0.319 * * *$ & $0.255 * * *$ & $0.161 * *$ \\
\hline 2009 & $0.246 * * *$ & $0.344 * * *$ & $0.291 * * *$ & $0.208 * * *$ & $0.161 * *$ & $0.294 * * *$ & $0.264 * * *$ & $0.147 * * *$ \\
\hline 2010 & $0.243 * * *$ & $0.337 * * *$ & $0.31 * * *$ & $0.204 * * *$ & $0.166 * *$ & $0.198 * * *$ & $0.285^{* * *}$ & $0.215 * * *$ \\
\hline 2011 & $0.259 * * *$ & $0.341 * * *$ & $0.271 * * *$ & $0.291 * * *$ & $0.165 * *$ & $0.221 * * *$ & $0.272 * * *$ & $0.208 * * *$ \\
\hline 2012 & $0.251 * * *$ & $0.321 * * *$ & $0.274 * * *$ & $0.261 * * *$ & $0.163 * *$ & $0.239 * * *$ & $0.28 * * *$ & $0.23 * * *$ \\
\hline 2013 & $0.25 * * *$ & $0.286 * * *$ & $0.213 * * *$ & $0.275 * * *$ & $0.158 * *$ & $0.248 * * *$ & $0.292 * * *$ & $0.249 * * *$ \\
\hline 2014 & $0.256 * * *$ & $0.262 * * *$ & $0.239 * * *$ & $0.266 * * *$ & $0.153 * *$ & $0.237 * * *$ & $0.287 * * *$ & $0.256 * * *$ \\
\hline 2015 & $0.278 * * *$ & $0.279 * * *$ & $0.219 * * *$ & $0.242 * * *$ & $0.164 * *$ & $0.303 * * *$ & $0.3 * * *$ & $0.249 * * *$ \\
\hline
\end{tabular}

351

352

Table 10 Robustness check: a new of regression method

\begin{tabular}{lccccccc}
\hline VARIABLES & Model 1 & Model 2 & Model 3 & Model 4 & Model 5 & Model 6 & Model 7 \\
\hline ED & $0.293^{* * *}$ & & & & & \\
& $(3.02)$ & & & & & \\
PED & & $8.469 * * *$ & & & &
\end{tabular}

MED

$6.643 * * *$

CED

1.989

(0.79)

EAD

$0.132 * *$

(2.12)

EMD

$0.151 * *$

(2.06)

ESD

0.096

(1.58)

Control variable

YES

YES

YES

YES

YES

YES

YES

$\rho$

$0.167 * *$

$0.179 * *$

$0.213 * * *$

$0.252 * * *$

$0.212 * * *$

$0.206 * * *$

$0.253^{* * *}$

(2.19)

(2.38)

(2.86)

(3.48)

(2.84)

(2.75)

(3.50)

Province FE

YES

YES

YES

YES

YES

YES

Time FE

YES

YES

YES

YES

YES

YES

$\mathrm{N}$

480

480

480

480

480

480

480

Log likelihood-be

91.543

91.362

88.594

81.952

87.098

86.080

82.812 


\section{Conclusions and policy implications}

Using panel data of 30 provinces in China during the period 2000 to 2015, this study examined the effect of different types of environmental decentralization on regional green innovation from a heterogeneous perspective. The conclusions are as follows: Firstly, environmental decentralization can encourage green innovation. Secondly, for different environmental management of levels, the improvement of provincial-level environmental decentralization and municipal-level environmental decentralization can has significant promotional effects on green innovation. For different environmental management of affairs, environmental administrative decentralization and environmental monitoring decentralization have positive impacts on green innovation. Thirdly, the influence between different types of environmental decentralization and green innovation in different regions is different. In the eastern region, we find that regional green innovation is positively correlated with environmental decentralization. It is also correlated with provincial-level environmental decentralization and municipallevel environmental decentralization as well as environmental administrative decentralization and environmental monitoring decentralization. In the central region, environmental decentralization, county-level environmental decentralization, environmental monitoring decentralization and environmental supervision decentralization significantly have positive impacts on regional green innovation. In the western region, only environmental administrative decentralization exerts a positive role in regional green innovation, whereas environmental supervision decentralization negatively affects regional green innovation.

Based upon the conclusions above and the realities of environmental management in China, the following policy implications are provided as follows.

Firstly, environmental decentralization must be encouraged. In China, the central government should actively promote the reforms in the environmental decentralization system, provide local governments with greater autonomy in the use of personnel deployment and capital in environmental protection departments, and enable local governments to rely on their own information advantages of environmental pollution 
treatment. This action can improve the pertinence and effectiveness of environmental pollution control and make effective use of investment in environmental pollution control to promote green innovation.

Secondly, different environmental decentralization modes must be applied. From the perspective of environmental management levels, provincial-level environmental decentralization and municipal-level environmental decentralization should be improved. For environmental management affairs, local governments should enhance environmental administrative decentralization and environmental monitoring decentralization.

Finally, differentiated environmental decentralization strategies should be formulated in different regions. As the economic development in China's various regions is unbalanced, different environmental decentralization modes have different impacts on green innovation of different regions. The eastern region should strengthen environmental decentralization, provincial-level environmental decentralization, municipal-level environmental decentralization, environmental administrative decentralization and environmental monitoring decentralization. For the central region, environmental decentralization, county-level environmental decentralization, environmental monitoring decentralization, and environmental supervision decentralization should be encouraged. The western region should actively promote environmental administrative decentralization.

This study quantitatively investigates the impact of environmental decentralization on regional green innovation in China and has limitations that could be possible future research directions. Firstly, this study discusses the direct effect of environmental decentralization on regional green innovation, but does not consider a more complicated framework to understand environmental decentralization-regional green innovation mechanisms, such as the threshold effect of environmental decentralization and the moderating effect of fiscal decentralization. Secondly, as regional green innovation activities have spatial autocorrelation (Dong et al., 2020), our research focuses on the impact of environmental decentralization on regional green innovation, but does not consider the importance of spatial spillovers in the explanation of regional 
413 green innovation. Future research should consider using spatial econometric models to 414 investigate both the intra and interregional spatial effects between environmental 415 decentralization and regional green innovation.

Authors' contributions Y.N: Conceptualization, formal analysis, writingreview \& editing, data curation, writing-original draft. L.Q: Methodology, software, investigation, writing-review \& editing, validation.

Data availability Not applicable

\section{Compliance with ethical standards}

Ethical approval Not applicable.

Consent to participate Not applicable.

Consent to publish Not applicable.

Conflict of interest The authors declare that they have no conflict of interest. 


\section{Reference}

Albort-Morant, G., Leal-Millan, A., Cepeda-Carrion, G., 2016. The antecedents of green innovation performance: A model of learning and capabilities. Journal of Business Research 69(11), 49124917.

Amore, M.D., Bennedsen, M., 2016. Corporate governance and green innovation. Journal of Environmental Economics and Management 75, 54-72.

Batterbury, S.P.J., Fernando, J.L., 2006. Rescaling governance and the impacts of political and environmental decentralization: An introduction. World Development 34(11), 1851-1863.

Bian, Y.C., Song, K.Y., Bai, J.H., 2019. Market segmentation, resource misallocation and environmental pollution. Journal of Cleaner Production 228, 376-387.

Boons, F., Montalvo, C., Quist, J., Wagner, M., 2013. Sustainable innovation, business models and economic performance: an overview. Journal of Cleaner Production 45, 1-8.

Cai, X., Zhu, B.Z., Zhang, H.J., Li, L., Xie, M.Y., 2020. Can direct environmental regulation promote green technology innovation in heavily polluting industries? Evidence from Chinese listed companies. Science of the Total Environment 746, 140810.

Chen, X.H., Yi, N., Zhang, L., Li, D.Y., 2018. Does institutional pressure foster corporate green innovation? Evidence from China's top 100 companies. Journal of Cleaner Production 188, 304-311.

Chen, Y.S., Lai, S.B., Wen, C.T., 2006. The influence of green innovation performance on corporate advantage in Taiwan. Journal of Business Ethics 67(4), 331-339.

Cuerva, M.C., Triguero-Cano, A., Corcoles, D., 2014. Drivers of green and non-green innovation: empirical evidence in Low-Tech SMEs. Journal of Cleaner Production 68, 104-113.

Dong, Z.Q., He, Y.D., Wang, H., Wang, L.H., 2020. Is there a ripple effect in environmental regulation in China? - Evidence from the local-neighborhood green technology innovation perspective. Ecological Indicators 118.

Feng, S.L., Sui, B., Liu, H.M., Li, G.X., 2020. Environmental decentralization and innovation in China. Economic Modelling 93, 660-674.

Fredriksson, P.G., Wollscheid, J.R., 2014. Environmental decentralization and political centralization. Ecological Economics 107, 402-410.

Fussler, C., 1996. Driving eco-innovation : a breakthrough discipline for innovation and sustainability, in: James, P. (Ed.). Pitman Publishing, London.

Hao, Y., Wang, L.O., Lee, C.C., 2020. Financial development, energy consumption and China's economic growth: New evidence from provincial panel data. International Review of Economics \& Finance 69, 1132-1151.

Hao, Y.J., Fan, C.C., Long, Y.G., Pan, J.Y., 2019. The role of returnee executives in improving green innovation performance of Chinese manufacturing enterprises: Implications for sustainable development strategy. Business Strategy and the Environment 28(5), 804-818. 
Hu, S.M., Liu, S.L., 2019. Do the coupling effects of environmental regulation and R\&D subsidies work in the development of green innovation? Empirical evidence from China. Clean Technologies and Environmental Policy 21(9), 1739-1749.

Kunapatarawong, R., Martinez-Ros, E., 2016. Towards green growth: How does green innovation affect employment? Research Policy 45(6), 1218-1232.

Leenders, M., Chandra, Y., 2013. Antecedents and consequences of green innovation in the wine industry: the role of channel structure. Technology Analysis \& Strategic Management 25(2), 203-218.

Li, D., Zheng, M., Cao, C., Chen, X., Ren, S., Huang, M., 2017. The impact of legitimacy pressure and corporate profitability on green innovation: Evidence from China top 100. Journal of Cleaner Production 141, 41-49.

Lin, H., Zeng, S.X., Ma, H.Y., Qi, G.Y., Tam, V.W.Y., 2014. Can political capital drive corporate green innovation? Lessons from China. Journal of Cleaner Production 64, 63-72.

Liu, L., Zhang, B., Bi, J., 2012. Reforming China's multi-level environmental governance: Lessons from the 11th Five-Year Plan. Environmental Science \& Policy 21, 106-111.

Liu, Q.L., Wang, Q., 2017. How China achieved its 11th Five-Year Plan emissions reduction target: A structural decomposition analysis of industrial SO2 and chemical oxygen demand. Science of the Total Environment 574, 1104-1116.

Liu, S.X., Zhu, Y.M., Du, K.Q., 2017. The impact of industrial agglomeration on industrial pollutant emission: evidence from China under New Normal. Clean Technologies and Environmental Policy 19(9), 2327-2334.

Luo, Y.S., Salman, M., Lu, Z.N., 2021. Heterogeneous impacts of environmental regulations and foreign direct investment on green innovation across different regions in China. Science of the Total Environment 759(2), 143744.

Ning, L.T., Wang, F., Li, J., 2016. Urban innovation, regional externalities of foreign direct investment and industrial agglomeration: Evidence from Chinese cities. Research Policy 45(4), 830-843.

Oltra, V., Jean, M.S., 2009. Sectoral systems of environmental innovation: An application to the French automotive industry. Technological Forecasting and Social Change 76(4), 567-583.

Pan, X., Cheng, W.Y., Gao, Y.N., Balezentis, T., Shen, Z.Y., 2020. Is environmental regulation effective in promoting the quantity and quality of green innovation? Environmental Science and Pollution Research 28(4), 6232-6241.

Pan, X.F., Li, M.N., Guo, S.C., Pu, C.X., 2020. Research on the competitive effect of local government's environmental expenditure in China. Science of the Total Environment 718, 110.

Qi, Y.L., H. Xu, Y, 2014. Research on reformation of China's environmental decentralization system: institutional change,quantitative measurement and effect evaluation China Industrial Economics 01, 31-43.

Ran, Q.Y., Zhang, J.N., Hao, Y., 2020. Does environmental decentralization exacerbate China's 
carbon emissions? Evidence based on dynamic threshold effect analysis. Science of the Total Environment 721, 137656.

Ren, S.G., Wang, Y., Hu, Y.C., Yan, J., 2021. CEO hometown identity and firm green innovation. Business Strategy and the Environment 30(2), 756-774.

Schiederig, T., Tietze, F., Herstatt, C., 2012. Green innovation in technology and innovation management - an exploratory literature review. R \& D Management 42(2), 180-192.

Shen, C., Li, S.L., Wang, X.P., Liao, Z.J., 2020. The effect of environmental policy tools on regional green innovation: Evidence from China. Journal of Cleaner Production 254, 120122.

Song, M.L., Wang, S.H., Zhang, H.Y., 2020. Could environmental regulation and R\&D tax incentives affect green product innovation? Journal of Cleaner Production 258, 120849.

Wang, Q.H., Qu, J.S., Wang, B., Wang, P.L., Yang, T.B., 2019. Green technology innovation development in China in 1990-2015. Science of the Total Environment 696, 134008.

Wu, H.T., Li, Y.W., Hao, Y., Ren, S.Y., Zhang, P.F., 2020. Environmental decentralization, local government competition, and regional green development: Evidence from China. Science of the Total Environment 708, 135085.

Yang, N., Hong, J., Wang, H., Liu, Q., 2020. Global value chain, industrial agglomeration and innovation performance in developing countries: insights from China's manufacturing industries. Technology Analysis \& Strategic Management 32(11), 1307-1321.

Yang, N.N., Liu, Q.M., Qi, Y., 2020. Does (un)-related variety promote regional innovation in China? Industry versus services sector. Chinese Management Studies 14(3), 769-788.

Yang, Z., Ali, S.T., Ali, F., Sarwar, Z., Khan, M.A., 2020. Outward foreign direct investment and corporate green innovation: An institutional pressure perspective. South African Journal of Business Management 51(1).

Yu, H., Zhiqiang, G., Guanpeng, Y., Haitao, W., Muhammad, I., 2021. The spatial spillover effect and nonlinear relationship analysis between environmental decentralization, government corruption and air pollution: Evidence from China. Science of the Total Environment 763, 144183.

Zang, J.N., Liu, L.L., 2020. Fiscal decentralization, government environmental preference, and regional environmental governance efficiency: evidence from China. Annals of Regional Science 65(2), 439-457.

Zeng, W.P., Li, L., Huang, Y., 2021. Industrial collaborative agglomeration, marketization, and green innovation: Evidence from China's provincial panel data. Journal of Cleaner Production 279, 123598.

Zhang, W., Li, G.X., 2020. Environmental decentralization, environmental protection investment, and green technology innovation. Environmental Science and Pollution Research 24(12).

Zhao, J., Zhao, Z.R., Zhang, H., 2021. The impact of growth, energy and financial development on environmental pollution in China: New evidence from a spatial econometric analysis. Energy Economics 93, 104506.

Zhen, H.F., Hu, H., Xie, N., Zhu, Y.Q., Chen, H., Wang, Y., 2020. The heterogeneous influence of 
economic growth on environmental pollution: evidence from municipal data of China. Petroleum Science 17(4), 1180-1193.

Zheng, W., 2021. Effects of China's market-oriented economic reform, FDI inflows on electricity intensity. Energy 220, 119934.

Zhou, C.Y., Hong, J., Wu, Y.R., Marinova, D., 2019. Outward foreign direct investment and domestic innovation performance: evidence from China. Technology Analysis \& Strategic Management 31(1), 81-95.

Zhou, K., Zhou, B.C., Yu, M.M., 2020. The impacts of fiscal decentralization on environmental innovation in China. Growth and Change 51(4), 1690-1710.

Zou, X., Lei, C., Gao, K.Y., Hu, C., 2019. Impact of Environmental Decentralization on Regional Green Development. Journal of Environment \& Development 28(4), 412-441. 